\title{
Long-Term Efficacy of Nevirapine Plus Co-Formulated Abacavir/ Lamividune as Simplification Therapy in HIV-Infected Patients with Undetectable Viral Load
}

\author{
Alfonso Cabello*, José Casas, Juan Alfredo López, Rosa García Delgado, Manuel L. Fernández Guerrero and Miguel Górgolas
}

Division of Infectious Diseases, Fundación Jiménez Díaz, Avda Reyes Católicos, Madrid, Spain

\begin{abstract}
Background: The long-term efficacy of NVP+ABC+3TC as a simplification strategy for the treatment of HIV-1 infected patients with undetectable viral load has not been properly assessed in randomized trials. This low-cost treatment with limited renal and bone side effects must be of particular interest in this era of cost-containment urgency and also in limited resource settings.
\end{abstract}

Methods: Observational study of 232 HIV1-infected patients with undetectable viral load who initiated nevirapine (NVP) + abacavir (ABC) + lamivudine (3TC). Reasons for the switching were treatment simplification (56\%), renal problems $(6 \%)$, osteopenia/osteoporosis $(7 \%)$, hyperlipidemia $(11 \%)$ and others $(20 \%)$. HIV-1 viral load, CD4 cell count and fasting biochemistry profiles were determined on a routine clinical practice. The aim of the study was to evaluate long-term efficacy of this combination and its effect on renal function and lipid metabolism.

Results: 232 patients had a mean follow-up of 4 years (712 patients-year). The mean increment of CD4 after 4 years was 83 cells $/ \mu \mathrm{L}$ (13\% from baseline). Viral load remained undetectable in all but 14 patients $(6 \%)$. Triglycerides levels decreased by $10 \%$ overtime $(p<0,05) .25$ patients $(10,7 \%)$ stopped therapy due to NVP associated side effects; no $A B C$ associated side-effects were observed. No changes were found in renal function or bone mineral density.

Conclusions: The combination of NVP+ABC+3TC is a safe option for maintaining longterm viral suppression and immunological control, preserving renal function and improving hypertriglyceridemia.

Keywords: HIV; Nevirapine; Abacavir; Lamivudine; Simplification

Abbreviations: HAART: Highly Active Antiretroviral Therapy; HIV: Human Immunodeficiency Virus; HBV: Hepatitis B Virus; HCV: Hepatitis C Virus; IDU: Intravenous Drug User; NNRTIs: Non-Nucleoside Reverse Transcriptase Inhibitors; NRTIs: Nucleoside Reverse Transcriptase Inhibitors; NVP: Nevirapine; ABC: Abacavir; 3TC: Lamivudine; PIs: Protease Inhibitors.

\section{Introduction}

Nevirapine (NVP) is a first-generation NNRTI, cheap and widely available around the world. It has been safely and successfully used in naïve patients [1-4] although in females with $\mathrm{CD} 4+\mathrm{T}$ cell counts above 250 per $\mathrm{ml}$ and in males with counts above 400 cells per ml must be administered cautiously [5]. However, nevirapine is not included as a preferred regimen in up-dated guidelines [6,7] for naïve patients, but it has been and still is, commonly used in treatment simplification strategies. Nevertheless, nevirapine must be a very convenient drug in resource-limited settings and its use is increasing worldwide, as it was included as a recommended regimen in $\mathrm{WHO}$ guidelines [8].

Nevirapine has been extensively used in developed countries as a simplification strategy for HIV-1 patients intolerant to efavirenz or regimens containing PIs [9-11]. In these cases the number of CD4+ cells as a restriction criteria in naïve patients does not apply because the risk of nevirapine hypersensitivity is considered very low [12], and long-term efficacy is expected, as long as patient compliance is maintained.

In both situations, naive and simplification regimens, the preferred drugs combined with nevirapine have been tenofovir diproproxile (TDF) and emtricitabine (FTC), because the initial tolerance and efficacy of TDF, seemed to be better than that of abacavir (ABC) [1315]. However, as time has passed, clinicians are increasingly concern with the long-term toxicity of TDF either on the renal function and bone mineral density $[13,16]$ and, as HIV patients are becoming older, TDF sparing regimens are more attractive and becoming popular [17, 13]. However, there is a scarcity of information on the efficacy, risk of virology failure and benefits of this combination. Therefore, we design a study to assess the combination of nevirapine with a back-bone of $\mathrm{ABC}$ and $3 \mathrm{TC}$, as a strategy for preserving antiretroviral efficacy, renal function and bone mineral density.

\section{Methods}

Observational, retrospective longitudinal study of 232 HIVinfected patients on HAART that included NVP+ABC+3TC with the following characteristics: a) viral load suppression $(<50$ copies $/ \mathrm{ml})$ and: b) a reason for EFV or PI discontinuation (central nervous system side-effect, hypercholesterolemia, hypertriglyceridemia, lypodistrophy, colicky renal pain, others); or c) a reason for TDF discontinuation (increased serum creatinine, osteopenia/osteoporosis or simply a voluntary treatment change as a preventive strategy); or d) voluntary treatment simplification (medical decision).

*Corresponding author: Alfonso Cabello, Division of Infectious Diseases, Fundación Jiménez Díaz, Avda Reyes Católicos, Madrid 28040, Spain, Tel: +34 915504800; E-mail: alcubeda@yahoo.es

Received April 11, 2015; Accepted May 04, 2015; Published May 14, 2015

Citation: Cabello A, Casas J, López JA, Delgado RG, Guerrero MLF, et al. (2015) Long-Term Efficacy of Nevirapine Plus Co-Formulated Abacavir/Lamividune as Simplification Therapy in HIV-Infected Patients with Undetectable Viral Load. J AIDS Clin Res 6: 457. doi:10.4172/2155-6113.1000457

Copyright: ( 2015 Cabello A, et al. This is an open-access article distributed unde the terms of the Creative Commons Attribution License, which permits unrestricted use, distribution, and reproduction in any medium, provided the original author and source are credited. 
Citation: Cabello A, Casas J, López JA, Delgado RG, Guerrero MLF, et al. (2015) Long-Term Efficacy of Nevirapine Plus Co-Formulated Abacavir/ Lamividune as Simplification Therapy in HIV-Infected Patients with Undetectable Viral Load. J AIDS Clin Res 6: 457. doi:10.4172/21556113.1000457

Page 2 of 5

The aim of the study was:

1.- To evaluate the long-term ( $>3$ years) efficacy of the combination of NVP plus ABC plus 3TC in maintaining viral suppression and CD4+ lymphocyte counts.

2.- To evaluate the tolerance and side-effects of the new combination after long-term use

3.- To assess the short and long-term evolution of biochemical abnormalities associated with TDF after withholding therapy.

In all cases NVP was started at the doses of $200 \mathrm{mg}$ once a day during two weeks and then increased to $200 \mathrm{mg}$ bid or $400 \mathrm{mg}$ qd. Since the introduction of HLA-B $57^{\star} 01$ determination, $\mathrm{ABC}$ was started only when was negative. The study was conducted during a period of 89 months (from January 2007 to May 2014) in one university hospital in downtown Madrid.

This is an observational retrospective study of routine clinical practice; therefore informed consent was not obtained from patients. We obtained the approval of the Ethics Committee Fundación Jiménez Díaz for review the clinical histories, and the patient records/ information was anonymized and de-identified prior to analysis.

\section{Definitions}

Lipodystrophy was defined as redistribution of peripheral fat (lipoatrophy of the face, arms, legs, buttocks) or central obesity. This was accepted when both the patient's belief and the doctor's physical examination agreed. Dyslipidaemia was diagnosed according to the serum levels published by NCEP-ATPII in 1994: hypercholesterolemia was defined when fasting serum total cholesterol levels were higher than $200 \mathrm{mg} / \mathrm{dL}$ and hypertriglyceridemia was defined when fasting serum triglycerides levels were higher than $200 \mathrm{mg} / \mathrm{dL}$. Renal dysfunction was considered when the value of serum creatinine was $\geq$ $1,4 \mathrm{mg} / \mathrm{dL}$ (normal range $0,7-1,3$ ). Nephrolithiasis was determined by repeated episodes of colicky renal pain with abnormalities in the urine sediment (haematuria or crystalluria) and utrasonography. Efficacy was defined in terms of success in viral suppression $(<50$ copies $/ \mathrm{mL})$. Viral rebound was defined as the presence of $\geq 200$ copies $/ \mathrm{mL}$ in two consecutive samples at least one month apart. Tolerance was defined as the absence of side-effects associated to NVP. Side-effects and drug interactions associated with NVP therapy were those that developed after the introduction of the drug as described in the literature [1119] and included: rash, hepatotoxicity, and methadone withdrawal syndrome due to induction of cytochrome P-450 system. Hepatotoxicity secondary to NVP use was defined as an increase greater than 3-fold the upper normal values of SGOT or SGPT. Changes in $\gamma$-GGT levels were not considered.

Patients were evaluated at baseline (at the time of NVP+ABC+3TC initiation) and every $4-6$ months thereafter, as in routine clinical practice. Physical examination, haematology and biochemistry tests (fasting glycaemia, cholesterol, triglycerides and creatinine), CD4+ cell count and viral load (Ultrasensitive Amplicor ${ }^{\circledR}$ Roche-viral load level detection 50 copies $/ \mathrm{ml}$ ), were performed at each visit. HLA-B57 ${ }^{\star} 01$ was performed using PCR-SSO (Inno-Lipa HLA-B; Fujirebio, Japan). Dexa bone scan was performed with Hologic ${ }^{\circledR} 4500$ in patients when indicated.

\section{Statistical analysis}

Description of data was performed using percentages, means and standard deviation and median and interquartile range. Quantitative variables were analysed by Kolmogorov-Smirnoff test to confirm normality of data. When no normality was found, logarithmic transformation was performed. The comparison between basal values and values over the time was performed by paired t-test. Qualitative variables were analysed by McNemar test for comparison of proportions over the time in a group. The results were analysed using the SPSS version 9.0 software package. Statistical significance was assumed for $p<0.05$.

\section{Results}

\section{Baseline demographic, virological and immunological features of patients}

Two hundred and thirty-two patients were included in the study. The mean age of patients was 47 years (range 16-83); 207 were male (89\%) and 25 female (11\%). The risk factors for HIV acquisition were: sex among men 182 (78\%), intravenous drug abuse 32 (14\%) and others $14(8 \%)$. The clinical HIV categories at the time of switching were: A $181(78 \%)$, B $20(8,6 \%)$, C $29(12,4 \%)$; and the mean $\left( \pm\right.$ SD) $\mathrm{CD}^{+}$cell count was $620 \pm 277$ cells/ $\mu \mathrm{L}$; median 605 (range 71-1530).

49 patients (21\%) had been on a PI's based therapy prior NVP initiation (3 SQV, 15 LPV, 2 DRV, 14 FPV and 9 ATV); 37 patients (16\%) had been on EFV based therapy; and 12 patients had triple NRTI's therapy. The mean time on effective HAART before NVP introduction was 57 months. In relation to NRTI's, 122 patients ( $52 \%$ ) were on TDF before switching to $\mathrm{ABC}$. The main clinical characteristics of patients are summarized in Table 1.

Regarding co-infection with hepatitis viruses, serologic tests were available in all but 25 patients; 7 patients were chronically infected with $\mathrm{HBV}, 19$ patients had positive serology for $\mathrm{HCV}$ and 210 patients were negative for both viruses.

We classified patients depending on the main reason for switching, as follows: voluntary treatment simplification 129 patients (55\%), most of them (104/129) switched the NRTI backbone (TDF/FTC by $\mathrm{ABC} / 3 \mathrm{TC})$; PI's associated toxicity -diarrhoea 10 patients $(4 \%)$, EFV associated toxicity 14 patients (6\%), lipodystrophy 9 patients $(3,8 \%)$, TDF associated toxicity 15 patients $(6 \%)$ (renal dysfunction

\begin{tabular}{|c|c|}
\hline Characteristic & Value \\
\hline$N^{\circ}$ of patients & 232 \\
\hline Age (range) & $47(16-83)$ \\
\hline $\begin{array}{l}\text { Sex } \\
\text { Male } \\
\text { Female }\end{array}$ & $\begin{array}{r}207(89 \%) \\
25(11 \%)\end{array}$ \\
\hline $\begin{array}{l}\text { Risk factor (Mode of transmission) } \\
\text { MSM } \\
\text { Parenteral } \\
\text { Others }\end{array}$ & $\begin{array}{r}182(78 \%) \\
32(14 \%) \\
18(8 \%)\end{array}$ \\
\hline $\begin{array}{l}\text { CDC HIV infection category } \\
\text { A } \\
\text { B } \\
\text { C }\end{array}$ & $\begin{array}{r}181(78 \%) \\
20(9 \%) \\
29(12 \%)\end{array}$ \\
\hline $\begin{array}{l}\text { Race } \\
\text { Caucasian } \\
\text { Latin } \\
\text { Others }\end{array}$ & $\begin{array}{r}170(73 \%) \\
52(22 \%) \\
10(5 \%)\end{array}$ \\
\hline $\begin{array}{l}\text { Hep C or B serology } \\
\text { Positive Hep C serology } \\
\text { Positive Ag HBs serology }\end{array}$ & $\begin{array}{r}19(8 \%) \\
7(3 \%)\end{array}$ \\
\hline $\begin{array}{l}\text { Cumulative duration of ART in months (mean), } \\
\text { (IQR) }\end{array}$ & $57(22-88)$ \\
\hline 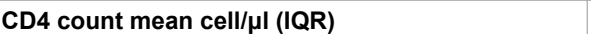 & $620(408-780)$ \\
\hline
\end{tabular}


Citation: Cabello A, Casas J, López JA, Delgado RG, Guerrero MLF, et al. (2015) Long-Term Efficacy of Nevirapine Plus Co-Formulated Abacavir/ Lamividune as Simplification Therapy in HIV-Infected Patients with Undetectable Viral Load. J AIDS Clin Res 6: 457. doi:10.4172/21556113.1000457

Page 3 of 5

\begin{tabular}{|c|c|c|c|}
\hline Characteristic & Baseline & \multicolumn{2}{|c|}{ End of follow-up } \\
\hline CD4 cell count (mean, cell/pl) & $620 \pm 277$ & $703 \pm 290$ & $p<0,001$ \\
\hline $\begin{array}{l}\text { Serum cholesterol levels (mean, } \mathrm{mg} / \mathrm{dL} \text { ) } \\
\text { Patients with serum cholesterol levels }>200 \mathrm{mg} / \mathrm{dL} \text { ( } 125 \mathrm{p} \text { ) }\end{array}$ & $\begin{array}{l}209 \pm 45 \\
240 \pm 35\end{array}$ & $\begin{array}{l}203 \pm 43 \\
218 \pm 42\end{array}$ & $\begin{array}{l}p=0,032 \\
p<0,001\end{array}$ \\
\hline $\begin{array}{l}\text { Serum triglycerides levels (mean, } \mathrm{mg} / \mathrm{dL} \text { ) } \\
\text { Patients with serum triglycerides levels }>200 \mathrm{mg} / \mathrm{dL}(71 \mathrm{p} \text { ) }\end{array}$ & $\begin{array}{l}191 \pm 159 \\
358 \pm 186\end{array}$ & $\begin{array}{l}167 \pm 169 \\
247 \pm 233\end{array}$ & $\begin{array}{l}p=0,027 \\
p<0,001\end{array}$ \\
\hline Serum LDL - cholesterol leves (mean, mg/dL) & $118 \pm 32$ & $118 \pm 29$ & $p=0,941$ \\
\hline Serum HDL - cholesterol leves (mean, mg/dL) & $30 \pm 14$ & $45 \pm 18$ & $p<0,001$ \\
\hline
\end{tabular}

Table 2: Inmunological and lipid profile of patients.

6 patients, osteopenia/osteoporosis 1 patient or just as a preventing strategy 8 patients); hyperlipidemia 46 patients (20\%) (isolated hypertriglyceridemia, hypercholesterolemia or both)

\section{Loss of follow-up}

20 patients $(8,5 \%)$ (7 during the first year, 6 during the second year, 3 during the third year, 2 during the fourth, and 2 during de sixth) were lost of follow up.

\section{Interruption of $\mathrm{NVP}+\mathrm{ABC}+3 \mathrm{TC}$ treatment}

73 patients (31\%) stopped treatment due to different reasons. NVP associated side-effects occurred in 25 patients $(10,7 \%)$; voluntary treatment interruption 11 patients $(4,7 \%)$; change to another simplified HAART regimen 11 patients (4,7\%); viral rebound 3 patients $(1,3 \%)$, lost of follow up 20 patients $(8,5 \%)$, and non-AIDS related deaths 3 patients $(1,3 \%)$ (gastric cancer, anal cancer an acute leukaemia). Sideeffects associated with the use of $A B C$ were not observed.

\section{Clinical, immunological and virological outcome}

The mean time of follow up was 48 months (range 20-86 months). At the time of writing $99 \%$ of patients are alive (only three patients died due to non-AIDS related causes). The mean CD4+ cell count increased to $703 \pm 290$ cells $/ \mu \mathrm{L}$, which represents a gain of 83 cells $(13 \%$, p NS) (p $<0,001$ ) from baseline values (Table 2 ). Viral load remained $<50$ copies/ $\mathrm{mL}$ along the study in all patients on NVP therapy but $14(6 \%) .11$ of these patients had an incomplete adherence to treatment. Viral rebound occurred in 6 cases within 3 and 6 months after NVP+ABC+3TC was begun, in 7 cases within 6 and 12 months and in one case four years after $\mathrm{NVP}+\mathrm{ABC}+3 \mathrm{TC}$ was started.

The intention to treat (ITT) analysis showed the following results: efficacy of NVP+ABC+3TC was: $191 / 232(82,33 \%)$ in the first year, $154 / 209(73,68 \%)$ in the second year, and $123 / 188(65,42 \%)$ in the third year. The on-treatment analysis results were: 191/232 (82,33\%), 154/168 $(91,66 \%)$ and $123 / 133(92,48 \%)$ in the $1^{\text {st }}, 2^{\text {nd }}$ and $3^{\text {rd }}$ year respectively.

When viral rebound occurred, detectable viral load values ranged between 3 and 5 logs. In 14 of the patients who had viral rebound, genotypic resistance tests showed resistance to NVP, ABC or 3TC in 8, 6 and 7 cases respectively. All these patients returned to undetectable viral load levels after reintroducing HAART that included a PI or RAL.

In a subgroup analysis of simplified patients who were previously receiving IPs (50p), EFV (37p) and ITIANs (12p) plus ABC and 3TC and switched to NVP maintaining the nucleoside backbone (ABC+3TC), showed an efficacy rate of $90 \%, 87 \%$ and $100 \%$ respectively.

\section{Assessment of metabolic abnormalities}

14 patients who developed renal dysfunction associated with TDF therapy were followed with periodic creatinine tests. All of them but one evolved favourably, showing a normalisation of creatinine values overtime. The serum creatinine remained high in this patient due to tenofovir toxicity combined with other nephrotoxic drugs (chemotherapy due to acute myeloid leukemia).

The lipid profile evolution is shown in Table 2.125 patients had serum cholesterol values $>200 \mathrm{mg} / \mathrm{dl}$ at the time of switching. In this group a statistically significant decrease of $9 \%$ in mean serum cholesterol levels was observed in serum cholesterol levels along the study $(\mathrm{p}<0,001)$. In the same way, a $50 \%$ increase in mean serum HDL-cholesterol levels was observed globally $(p<0,001)$. The mean percentage of reduction of the mean serum cholesterol levels from baseline was $3 \%$ until the last available follow up visit $(p=0,032)$. By the same token, the evolution of 71 patients who had serum triglycerides levels $>200 \mathrm{mg} / \mathrm{dL}$ showed a $31 \%$ reduction from baseline levels until the last available follow up visit $(\mathrm{p}<0,001)$.

\section{Assessment of EFV central nervous system side effects}

14 patients discontinued EFV due to CNS side-effects. In all cases the symptoms disappeared within the first weeks after EFV withdrawal.

\section{Nevirapine side effects}

25 patients (10,7\%) developed NVP associated side effects leading to treatment discontinuation. Acute icteric hepatitis was not observed in any patient. Nevertheless, 4 patients $(1,7 \%)$ had asymptomatic but significant elevations of transaminases, which occurred within the first year of treatment. After discontinuation, biochemical abnormalities returned to normal in all cases (grade toxicity 1 ). Hepatotoxicity was not associated to hepatitis B or C co-infection.

Seven patients (3\%) exhibited skin rashes (grade toxicity1), all of them but one within the first 2 weeks of NVP initiation. HLA-B57 ${ }^{\star} 01$ was negative in all of these seven cases. When NVP was withdrawn all symptoms had resolved. HLA-B57 01 was done in 190 patient and it was negative in 188 of them. The two patients who started $A B C$ with HLA-B57 ${ }^{\star} 01$ positive (unknown at the moment of beginning this regimen) did not present any reaction. None of the other 42 patients who HLA-B $57^{\star} 01$ was unknown presented any symptoms related. Finally, one patient developed acute methadone withdrawal syndrome after NVP was begun. It was probably unrelated but the physician, but the physician decided that NVP was withdrawn.

\section{Discussion}

Some studies have shown that switching PIs to non-nucleoside reverse transcriptase inhibitors may improve the quality of life of patients receiving HAART by reducing toxic and metabolic side-effects and by facilitating adherence to antiretroviral regimens $[11,18-20]$. In the same way TDF-sparing regimens may be attractive to avoid longterm renal or bone toxicity $[17,13,21]$. The combination of NVP plus $\mathrm{ABC}$ plus 3TC is a simplified TDF-sparing regimen that may be of some help to achieve these purposes. However, there is a lack of controlled randomized trials to assess its long-term efficacy. We therefore have retrospectively assessed the long-term efficacy and tolerability of 
Citation: Cabello A, Casas J, López JA, Delgado RG, Guerrero MLF, et al. (2015) Long-Term Efficacy of Nevirapine Plus Co-Formulated Abacavir/ Lamividune as Simplification Therapy in HIV-Infected Patients with Undetectable Viral Load. J AIDS Clin Res 6: 457. doi:10.4172/21556113.1000457

Page 4 of 5

$\mathrm{NVP}+\mathrm{ABC}+3 \mathrm{TC}$ in a cohort of HIV infected patients treated in a routine clinical practice [22]. This combination has a reduced cost and could be prescribed as two pills administered once daily, rendering it as a very attractive regimen, particularly in resource limited settings. However, although previous studies have shown the efficacy of NVP combined with TDF and other reverse transcriptase nucleosides analogues [9-11,13,18-20,23], the combination of NVP+ABC+3TC has not been properly assessed, not even in cohort studies like ours.

The most relevant finding of our study is that the long-term viral efficacy of the combination is very high, maintaining viral suppression in over $90 \%$ of cases, similar to that found in other simplification studies $[9,20,23,10]$. Incomplete adherence is the most frequent cause of viral rebound using this combination, and approximately half of the failing subjects will develop mutations of resistance to NVP, ABC or 3TC. The low genetic barrier of nevirapine for the development of resistance mutations is of particular concern and indicates that patients on therapy with this regimen must be carefully controlled. Fortunately all failing patients in this series returned to undetectable viral loads when treatment based on PI or RAL. The regimen seems robust in terms of immune reconstitution as CD4+T cell increments were observed and no AIDS-defining opportunistic infections occurred during the study.

As in most switching studies, toxicities related to discontinued drugs tended to disappear with the new regimen. This is the case for efavirenz-related CNS side- effects [24,25] or gastrointestinal PIassociated toxicity. By the same token, TDF renal dysfunction also improved when it was discontinued and $\mathrm{ABC}$ was introduced [26]. It has also been the case in our study.

Currently, HIV related comorbidities are major issues and the prevention of cardiovascular events by maintaining adequate lipids profiles and healthier habits is of paramount importance [27]. A significant reduction of triglycerides levels was observed in our cohort within the first year after the switch. Previous studies by Martinez [20] and Raffi [10] have shown similar results within the first six months of therapy in patients who were initially treated with ritonavir containing regimens.

NVP related side-effects may be particularly severe in naïve patients [28-31] but are much less severe and frequent when it has been used in treated patients with undetectable viral load $[25,32]$, as it has occurred in our study were $10 \%$ of our patients starting NVP had side-effects that led to drug discontinuation.

Our study has the inherent limitations of retrospective studies, however the large number of patients and the fact that the data was collected from routine clinical practice enhances its value.

In summary, our observations suggest that the combination of $\mathrm{NVP}+\mathrm{ABC}+3 \mathrm{TC}$ as a simplification strategy is safe and has long-term efficacy. This statement is supported by a recent study [33]. Its low cost and effectiveness for children and pregnant women has an additional benefit as other authors has previously noticed [34-39].

\section{References}

1. Dejesus E, Mills A, Bhatti L, Conner C, Storfer S (2011) A randomised comparison of safety and efficacy of nevirapine vs. atazanavir/ritonavir combined with tenofovir/emtricitabine in treatment-naïve patients. Int $\mathrm{J}$ Clin Pract 65: 1240-1249.

2. Lange JM (2003) Efficacy and durability of nevirapine in antiretroviral drug näive patients. J Acquir Immune Defic Syndr 34 Suppl 1: S40-52.

3. Ena J, Amador C, Benito C, Pasquau F (2012) Pharmacological and clinical evidence of nevirapine immediate- and extended-release formulations. HIV AIDS (Auckl) 4: 169-179.
4. Fisac C, Fumero E, Crespo M, Roson B, Ferrer E, et al. (2005) Metabolic benefits 24 months after replacing a protease inhibitor with abacavir, efavirenz or nevirapine. AIDS 19: 917-925.

5. Pharmacists A, Guide M. Viramune $\hat{A} \circledast$ ( nevirapine ) Tablets Viramune Â® ( nevirapine ) Oral Suspension Rx only. 1:4-28.

6. AIDS Info (2014) DHHS: Guidelines for prevention and treatment of opportunistic infections in HIV-infected adults and adolescents.

7. EACS Guidelines 7.02

8. WHO (2013) Consolidated Guidelines On The Use Of Antiretroviral Drugs For Treating And Preventing HIV Infection.

9. Gil P, de Górgolas M, Estrada V, Arranz A, Rivas P, et al. (2004) Long-term efficacy and safety of protease inhibitor switching to nevirapine in HIV-infected patients with undetectable virus load. Clin Infect Dis 39: 1024-1029.

10. Raffi F, Bonnet B, Ferré V, Esnault JL, Perré P, et al. (2000) Substitution of a nonnucleoside reverse transcriptase inhibitor for a protease inhibitor in the treatment of patients with undetectable plasma human immunodeficiency virus type 1 RNA. Clin Infect Dis 31: 1274-1278.

11. Ruiz L, Negredo E, Domingo P, Paredes R, Francia E, et al. (2001) Antiretroviral treatment simplification with nevirapine in protease inhibitor-experienced patients with hiv-associated lipodystrophy: 1-year prospective follow-up of a multicenter, randomized, controlled study. J Acquir Immune Defic Syndr 27 229-236

12. Kesselring AM, Wit FW, Sabin CA, Lundgren JD, Gill MJ, et al. (2009) Risk factors for treatment-limiting toxicities in patients starting nevirapine-containing antiretroviral therapy. AIDS 23: 1689-1699.

13. Günthard HF, Aberg JA, Eron JJ, Hoy JF, Telenti A, et al. (2014) Antiretroviral treatment of adult HIV infection: 2014 recommendations of the International Antiviral Society-USA Panel. JAMA 312: 410-425.

14. Sax PE, Tierney C, Collier AC, Fischl MA, Mollan K, et al. (2009) Abacavirlamivudine versus tenofovir-emtricitabine for initial HIV-1 therapy. N Engl J Med 361: 2230-2240.

15. Canale D, de Bragança AC, Gonçalves JG, Shimizu MH, Sanches TR, et al. (2014) Vitamin d deficiency aggravates nephrotoxicity, hypertension and dyslipidemia caused by tenofovir: role of oxidative stress and Renin-Angiotensin system. PLoS One 9: e103055.

16. Ryom L, Mocroft A, Kirk O, Worm SW, Kamara DA, et al. (2013) Association between antiretroviral exposure and renal impairment among HIV-positive persons with normal baseline renal function: the D:A:D study. J Infect Dis 207 1359-1369.

17. Achhra AC, Boyd MA, Law MG, Matthews GV, Kelleher AD, et al. (2014) Moving away from Ritonavir, Abacavir, Tenofovir, and Efavirenz (RATE)--agents that concern prescribers and patients: a feasibility study and call for a trial. PLoS One 9: e99530.

18. Negredo E, Cruz L, Paredes R, Ruiz L, Fumaz CR, et al. (2002) Virological, immunological, and clinical impact of switching from protease inhibitors to nevirapine or to efavirenz in patients with human immunodeficiency virus infection and long-lasting viral suppression. Clin Infect Dis 34: 504-510.

19. Negredo E, Ribalta J, Paredes R, Ferré R, Sirera G, et al. (2002) Reversal of atherogenic lipoprotein profile in HIV-1 infected patients with lipodystrophy after replacing protease inhibitors by nevirapine. AIDS 16: 1383-1389.

20. Martínez E, Conget I, Lozano L, Casamitjana R, Gatell JM (1999) Reversion of metabolic abnormalities after switching from HIV-1 protease inhibitors to nevirapine. AIDS 13: 805-810.

21. Calmy A, Fux CA, Norris R, Vallier N, Delhumeau C, et al. (2009) Low bone mineral density, renal dysfunction, and fracture risk in HIV infection: a crosssectional study. J Infect Dis 200: 1746-1754.

22. Cabello Ãšbeda A, Sanz Moreno J, Williams F, GÃ ${ }^{3}$ rgolas M (2011) Efficacy and safety of nevirapine + Kivexa (abacavir/lamivudine) as a simplification strategy for HIV patients with undetectable viral load. J Acquir Immune Defic Syndr 58 95-96.

23. Barreiro P, Soriano V, Blanco F, Casimiro C, de la Cruz JJ, et al. (2000) Risks and benefits of replacing protease inhibitors by nevirapine in HIV-infected subjects under long-term successful triple combination therapy. AIDS 14: 807 812

24. Scourfield A, Zheng J, Chinthapalli S, Waters L, Martin T, et al. (2012) 
Citation: Cabello A, Casas J, López JA, Delgado RG, Guerrero MLF, et al. (2015) Long-Term Efficacy of Nevirapine Plus Co-Formulated Abacavir/ Lamividune as Simplification Therapy in HIV-Infected Patients with Undetectable Viral Load. J AIDS Clin Res 6: 457. doi:10.4172/21556113.1000457

Page 5 of 5

Discontinuation of Atripla as first-line therapy in HIV-1 infected individuals. AIDS 26: 1399-1401.

25. Parienti JJ, Massari V, Rey D, Poubeau P, Verdon R; SIROCCO study team (2007) Efavirenz to nevirapine switch in HIV-1-infected patients with dyslipidemia: a randomized, controlled study. Clin Infect Dis 45: 263-266.

26. Cooper RD, Wiebe N, Smith N, Keiser P, Naicker S, et al. (2010) Systematic review and meta-analysis: renal safety of tenofovir disoproxil fumarate in HIVinfected patients. Clin Infect Dis 51: 496-505.

27. Clotet B, van der Valk M, Negredo E, Reiss $P$ (2003) Impact of nevirapine on lipid metabolism. J Acquir Immune Defic Syndr 34 Suppl 1: S79-84.

28. Martínez E, Blanco JL, Arnaiz JA, Pérez-Cuevas JB, Mocroft A, et al. (2001) Hepatotoxicity in HIV-1-infected patients receiving nevirapine-containing antiretroviral therapy. AIDS 15: 1261-1268.

29. Bonnet F, Lawson-Ayayi $S$, Thiébaut $R$, Ramanampamonjy $R$, Lacoste $D$, et al. (2002) A cohort study of nevirapine tolerance in clinical practice: French Aquitaine Cohort, 1997-1999. Clin Infect Dis 35: 1231-1237.

30. Nachega JB, Hislop M, Dowdy DW, Gallant JE, Chaisson RE, et al. (2008) Efavirenz versus nevirapine-based initial treatment of HIV infection: clinical and virological outcomes in Southern African adults. AIDS 22: 2117-2125.

31. van Leth F, Andrews S, Grinsztejn B, Wilkins E, Lazanas MK, et al. (2005) The effect of baseline CD4 cell count and HIV-1 viral load on the efficacy and safety of nevirapine or efavirenz-based first-line HAART. AIDS 19: 463-471.

32. Winston A, Pozniak A, Smith N, Fletcher C, Mandalia S, et al. (2004) Dose escalation or immediate full dose when switching from efavirenz to nevirapinebased highly active antiretroviral therapy in HIV-1-infected individuals? AIDS 18: $572-574$
33. Kawalec P, Kryst J, Mikrut A, Pilc A (2013) Nevirapine-based regimens in HIVinfected antiretroviral-naive patients: systematic review and meta-analysis of randomized controlled trials. PLoS One 8: e76587.

34. Llibre JM, Cardona G, Santos JR, Andreu A, Estrada JO, et al. (2013) Antiretroviral treatment switch strategies for lowering the costs of antiretroviral therapy in subjects with suppressed HIV-1 viremia in Spain. Clinicoecon Outcomes Res 5: 215-221.

35. Gazzard B, Moecklinghoff C, Hill A (2012) New strategies for lowering the costs of antiretroviral treatment and care for people with HIVIAIDS in the United Kingdom. Clinicoecon Outcomes Res 4: 193-200.

36. Jamisse L, Balkus J, Hitti J, Gloyd S, Manuel R, et al. (2007) Antiretroviralassociated toxicity among HIV-1-seropositive pregnant women in Mozambique receiving nevirapine-based regimens. J Acquir Immune Defic Syndr 44: 371 376.

37. Aaron E, Kempf MC, Criniti S, Tedaldi E, Gracely E, et al. (2010) Adverse events in a cohort of HIV infected pregnant and non-pregnant women treated with nevirapine versus non-nevirapine antiretroviral medication. PLoS One 5 : e12617.

38. Fowler MG, Coovadia H, Herron CM, Maldonado Y, Chipato T, et al. (2014) Efficacy and safety of an extended nevirapine regimen in infants of breastfeeding mothers with HIV-1 infection for prevention of HIV-1 transmission (HPTN 046) 18-month results of a randomized, double-blind, placebo-controlled trial. Acquir Immune Defic Syndr 65: 366-374.

39. Tan DH, Chan K, Raboud J, Cooper C, Montaner JS, et al. (2011) Comparison of abacavir/lamivudine and tenofovir/emtricitabine among treatment-naive HIV infected patients initiating therapy. J Acquir Immune Defic Syndr 58: 38-46. 